\title{
Arsenic: an ancient toxicant of continuous public health impact, from Iceman Ötzi until now
}

\author{
Hermann M. Bolt
}

Published online: 26 May 2012

(C) Springer-Verlag 2012

Early knowledge on the toxicity of arsenicals has accumulated in Asian civilizations, where especially arsenic sulphide (realgar) had been traditionally used, both as a medicine and as a poison. According to Lewin (1929) such knowledge arrived at the Hellenic Mediterranean world following the conquests of Alexander the Great. Since then, there has been a continuous European history of both use of arsenic as a medicine and abuse as a homicide, until recently (Lewin 1929). For instance, Napoleon's health began rapidly to fail in February 1821. He suffered from chronic As intoxication when he died on 5 May 1821, as now evidenced by analysis of his hair (Kintz et al. 2007; see Table 1). Biomonitoring of As in human hair is now regarded to be a useful tool in field studies evaluating chronically elevated As exposures (Pandey et al. 2007; Orloff et al. 2009; Kazi et al. 2011), although being less indicative at low (non-elevated) exposures (Cleland et al. 2009).

Soluble inorganic arsenic is acutely toxic, and ingestion of large doses leads to gastrointestinal symptoms, disturbances of cardiovascular and nervous system functions, and eventually death. In survivors, bone marrow depression, haemolysis, hepatomegaly, melanosis, polyneuropathy and encephalopathy may be observed (WHO 2001). Chronic human exposure has been linked to a variety of dermal symptoms of $\operatorname{arseni}(\mathrm{c}) \operatorname{osis}^{1}$ (i.e. exfoliative dermatitis, keratosis, vitiligo, skin cancer), peripheral neuropathy, encephalopathy, bronchitis, pulmonary fibrosis, hepato-splenomegaly, portal hypertension, peripheral vascular disease/"blackfoot disease", atherosclerosis, cancer

H. M. Bolt $(\bowtie)$

Leibniz Research Centre for Working Environment and Human Factors (IfADo), Ardeystr. 67, 44139 Dortmund, Germany

e-mail: bolt@ifado.de (lung, urinary bladder, other organs) and diabetes mellitus (Pimparker and Bhave 2010).

In contrast to its intentional use, arsenic as a chronic human environmental toxicant has an even much longer history by a couple of 1,000 years. At present, the oldest environmental exposure to arsenic is scientifically testified by hair analysis of the Tyrolean Neolithic mummy called "Ötzi", who died between 3359 and 3105 BC (Oeggl 2009). In his case, copper enrichment near the hair surface and high arsenic contents in keratin cells of the interior of the hair shaft strongly argue in favour of a long-term involvement in copper working, accompanied by high arsenic exposure (Brothwell and Grime 2002). Table 1 compares these data with contemporary concentrations of arsenic in hair. Regarding historical aspects, a challenging theory is now being advanced that desertion of several important Etruscan settlements at the end of the Archaic period in Italy had been a consequence of man-made pollution and associated arsenic environmental poisoning (Harrison et al. 2010).

According to the evaluation of WHO (2001), long-term exposure to arsenic in drinking water is causally related to increased risks of cancer in the skin, lungs, bladder and kidney, as well as other skin changes such as hyperkeratosis and pigmentation changes. These effects have been demonstrated in many studies using different study designs. Exposure-response relationships have been observed for each of these end-points. The effects have been most thoroughly studied in Taiwan, but there is considerable evidence from studies on populations in other countries as well. Increased risk of lung and bladder cancer and of

\footnotetext{
${ }^{1}$ In the present literature the terms arseniosis, arsenicosis and arseniasis are used without clear distinctions. In the present editorial, the denominations generally follow those of the respective authors.
} 
Table 1 Recently reported elevated As levels in human hair specimens (mean values; single data, when indicated)

\begin{tabular}{|c|c|c|}
\hline Geographic area and conditions & $\mu \mathrm{g}$ As/g hair & References \\
\hline \multicolumn{3}{|l|}{ (Pre-)historical } \\
\hline Neolithic Tyrolean “Ötzi” & $44^{\mathrm{a}}$ & Brothwell and Grime (2002) \\
\hline Saint Helena, Napoleon & $37.4,42.1$ & Kintz et al. (2007) \\
\hline \multicolumn{3}{|l|}{ Coal combustion } \\
\hline $\begin{array}{l}\text { Guizhou/China, indoor combustion of high-As coal, villages } \\
\text { with arseniosis cases }\end{array}$ & $43.4,48.6,53.5$ & Baoshan et al. (2005) \\
\hline $\begin{array}{l}\text { Slovakia, As-rich coal combustion in power plant, } \\
\text { environmental exposure }\end{array}$ & $>3$ & Bencko et al. (2009) \\
\hline \multicolumn{3}{|l|}{ Mining } \\
\hline \multirow[t]{2}{*}{ Xikuangshan $\mathrm{Sb}$ mining area, China, environmental exposure } & 3.99 & Wu et al. (2011) \\
\hline & 4.21 & Liu et al. (2009) \\
\hline Shantou, China, W mining area, environmental exposure & 2.92 & Liu et al. (2010) \\
\hline \multicolumn{3}{|l|}{ Food and drinking water } \\
\hline Pakistan, consumption of As-contaminated fish & Up to 4.94 & Shah et al. (2011) \\
\hline Gaighata, West Bengal, India, As in groundwater & Up to 5.99 & Roychowdhury (2010) \\
\hline Jalangi/Domkol, West Bengal, India, As in tube-well water & Up to 4.7 & Uchino et al. (2006) \\
\hline Kandal Province, Cambodia, As in groundwater & Up to 7.95 & Gault et al. (2008) \\
\hline An Giang, Mekong River Delta, Vietnam, As in drinking water & Up to $>10$ Hanh et al. (2011) & \\
\hline San Antonio de los Cobres, Argentina, As in drinking water & Up to 1.5 & Concha et al. (2006) \\
\hline Illapata, Chile, As in drinking water & 4.20 & Yanez et al. (2005) \\
\hline Santana, Brazil & Up to $23.8^{\mathrm{b}}$ & De Fátima Pinheiro Pereira (2010) \\
\hline \multicolumn{3}{|l|}{ Controls } \\
\hline Guizhou/China (see above) controls, no arseniosis & $0.56,0.60$ & Baoshan et al. (2005) \\
\hline Altamira/Amazon, Brazil & 0.43 & De Fátima Pinheiro Pereira (2010) \\
\hline Rio de Janeiro, Brazil & 0.70 & dto. \\
\hline Egypt & 0.54 & dto. \\
\hline Canada and USA & 0.01 & dto. \\
\hline Italy & 0.09 & dto. \\
\hline Malaysia & 0.28 & dto. \\
\hline UK reference, non-exposed, different ethnic groups & $0.116-0.141$ & Brima et al. (2006) \\
\hline
\end{tabular}

${ }^{a}$ Average As content (Brothwell and Grime 2002): $0.11 \%$ of S content; normal S content: $40 \mathrm{mg}$ S/g hair (Forslind et al. 1985)

${ }^{\mathrm{b}}$ Mean values between 0.56 and $6.49 \mu \mathrm{g}$ As/g hair, dependent on residence location

arsenic-associated skin lesions has been reported to be associated with ingestion of drinking water at concentrations $\geq 50 \mu \mathrm{g}$ arsenic/L (WHO 2001).

The textbook case of arsenic-related peripheral vascular disease was found in the early twentieth century, being endemic along the southwestern coast of Taiwan. The disease involved the lower extremities, characterized by typical clinical symptoms of progressive arterial occlusion; it was called "blackfoot disease" because of the gangrenous appearance of feet of patients. The prevalence of the disease ranged from 6.51 to 18.85 per 1,000 capita in different villages. Epidemiologic studies revealed that blackfoot disease was associated with the consumption of fossil Artesian well water containing high levels of arsenic. Co- occurrence of blackfoot disease and arsenic-related skin lesions such as hyperpigmentation, hyperkeratosis, and skin cancer was also observed. Recent studies confirmed the association also of preclinical peripheral vascular disease with arsenic exposure. The incidence of clinical manifestation of blackfoot disease decreased dramatically after the installation of tap water in these villages over the last 2-3 decades of the twentieth century (Tseng 2002). Thus, the number of publications on this classical disease has now decreased.

In essence, it is evident that over centuries exposures to arsenic continue to be a public major health problem in many countries. Because of this reason, arsenic is a priority matter for toxicological research in a number of countries. 
For Archives of Toxicology, this is clearly visualized by an increasing number of submitted manuscripts on arsenic toxicity. Hence, the journal dedicates a special issue to this topic, thereby providing an up-to-date insight into the diversity of the present toxicological research on arsenic.

\section{Contemporary focus on As exposures}

- Heavy metals, including arsenic, are being used in traditional medicines in Asia, which is being addressed as a major toxicological problem, for instance in China and India (Liu et al. 2008; Kamath et al. 2012). Recently, arsenic trioxide is being recommended for a very special medicinal use, that is, in the treatment for acute promyelocytic leukaemia (Emadi and Gore 2010).

- As can be seen from Table 1, the combustion of As-rich coal is a major reason for chronic intoxication, especially in some areas of China (Baoshan et al. 2005; Wang et al. 2007; Lin et al. 2010). As a worstcase reported from the Chinese Southwest Province of Guizhou, coal with an As content of up to 35,000 ppm is burned indoors in open pits for daily cooking and crop drying. In a few villages, approximately 3,000 patients with skin lesions indicative of chronic arsenicosis had been detected by 1998 (Baoshan et al. 2005). As already reported in Archives of Toxicology, genetic polymorphisms at XPD/ERCC2 appear to modulate the risk of arsenic-related skin lesions in such patients (Lin et al. 2010).

- High As concentrations in groundwater, especially in Southeast Asia, have received much attention in the past decade. This refers to the parts of India and Bangladesh, with groundwater levels equal or greater than $200 \mu \mathrm{g} / \mathrm{L}$ (Guha Mazumder and Dasgupta 2011), and especially the floodplain areas along the Mekong river (Laos, Cambodia, Vietnam). The source of elevated As concentrations in groundwater is considered to be release of As from river sediments, and it is estimated that more than 10 million residents in Southeast Asia are at risk from consuming As-contaminated groundwater (Kim et al. 2011). Data from Latin America show that this problem is not restricted to Asia. It has been estimated that some 4.5 million people in Latin America are chronically exposed to high levels of $\mathrm{As}(>50 \mu \mathrm{g} / \mathrm{L}$ drinking water), with extremes up to 2,000 $\mu \mathrm{g} / \mathrm{L}$ (McClintock et al. 2011). Such situations are being further investigated (de Fátima Pinheiro Pereira et al. 2010). The World Health Organization has recommended a provisional guideline value of $10 \mu \mathrm{g} / \mathrm{L}$ for arsenic in drinking water (WHO 1996).
- Co-exposure and possible interaction of As with other environmental toxicants is also a field of public concern. Most important is co-exposure to fluoride, both by ground water pollution (Chouhan and Flora 2010) and by indoor combustion of coal (Lin et al. 2012).

\section{Focal areas of present research}

The environmental situation, as described above, has triggered main avenues of present research. So far, only few environmental studies include a speciation of As (e.g., inorganic trivalent/pentavalent forms), and the present results are not entirely uniform (Sanz et al. 2007; de Fátima Pinheiro Pereira et al. 2010). Therefore, it ought to be expected that As speciation research will develop rapidly.

Connected with this field, a focal research point of the last years has been adsorption, distribution, metabolism and excretion (ADME) of As species/compounds (Dopp et al. 2008, 2010). It was soon recognized that the toxicities of As(III) and As(V) are different (Laib and Moritz 1989) and that the toxicity of $\mathrm{As}(\mathrm{V})$ results in part from its reduction to As(III) (Huang and Lee 1996). Metabolism of inorganic As proceeds mainly by a sequence of repetitive reduction and oxidative methylation steps, the latter mediated by arsenic methyl transferase (CYT19). A highly cited key publication of this journal by Hayakawa et al. (2005) has demonstrated that arsenic-glutathione complexes are substrates for the human CYT19. In general, toxicokinetics of As species remains an important experimental research focus, as evidenced by recent contributions to this journal (Kobayashi et al. 2008; Naraharisetti et al. 2008; Juárez-Reyes et al. 2009). In this issue, Chang et al. (2012) assess the role of specific cysteine residues in proteins for protein binding of arsenite.

As mentioned above, there may be relevant environmental co-exposures of As with other inorganic and organic compounds that lead to combined action, with questions of the mechanisms involved. In the present issue of Archives of Toxicology, Yajima et al. (2012) address apoptotic mechanisms induced by co-exposure with barium, which can additionally be present, at concentrations $>150 \mu \mathrm{g} / \mathrm{L}$, in As-containing ( $>200 \mu \mathrm{g} / \mathrm{L})$ drinking-water wells in Bangladesh. Two other publications in this issue address co-exposures of arsenic and fluoride. Lin et al. (2012) describe a population-based study in a rural area in Northwest China with a large number of cases diseased with a combination of arseniasis and fluorosis. The causal factor was again indoor combustion of coal rich in both As and $\mathrm{F}$, which led to extremely high co-exposures via the inhalation route. In an experimental study on rabbit aorta as 
a cardiovascular target, $\mathrm{Ma}$ et al. (2012) show that inflammatory responses play a critical role in the combined cardiovascular toxicity of As and F. Also, mechanisms involved in combined action of As and aryl hydrocarbon receptor ligands are being investigated (Anwar-Mohamed et al. 2012).

Indeed, with regard to the different manifestations of toxicity of arsenic (Singh et al. 2011), cardiovascular disorders, such as hypertension, atherosclerosis and myocardial injury, are receiving increased interest (Manna et al. 2008; Balakumar and Kaur 2009; Chen et al. 2012). A mechanism likely to be involved is oxidative stress, connected with activation of eNOS and enhanced the phosphorylation of MLCK (Singh et al. 2011). The entire field of As-induced oxidative stress and related signalling pathways is clearly of increasing scientific relevance (Flora 2011; Jomova and Valko 2011; Jomova et al. 2011; Tseng et al. 2012; Wang et al. 2012; Yen et al. 2012).

Oxidative stress plays a pivotal role in As-induced carcinogenesis (Shi et al. 2004). The public health impact of malignancies caused by arsenic is obvious. In this issue of Archives of Toxicology, authors from leading governmental US institutions (NTP, NIEHS, NCI) present a study that raises the serious concern of trans-placental carcinogenesis by a specific As compound, methylarsenous acid (Tokar et al. 2012). Against such a background, the priority of current research into mechanisms of As-induced malignant transformation is evident ( $\mathrm{Xu}$ et al. 2012).

There is now a remarkable development of genetic polymorphism studies, in conjunction with epidemiological research in As-exposed populations. A diversity of polymorphic enzymes is presently being investigated, including XPD/ERCC2 (Lin et al. 2010), arsenic methyl transferase (Agusa et al. 2009, 2010a), glutathione $S$-transferases (Agusa et al. 2010b), Mn-superoxide dismutase and 8-oxoguanine DNA glycosylase (Chen et al. 2012). A study published in this issue (Escobar-García et al. 2012) suggests a specific role of the glutathione S-transferase GSTO1-1 in As-mediated inflammatory response and apoptotic processes. The idea is put forward that the A140D and E208K polymorphisms increase the risk ofr inflammatory and apoptosis-related diseases in As-exposed populations. Although the present single studies generally require confirmation by independent studies/data sets, it appears that gene-environmental interactions focussing on human As exposures and As-induced effects are a very attractive and rapidly developing research area.

In essence, there is presently a rapid development of research into human environmental exposures to arsenic and related diseases, which are highly relevant to public health in a number of countries. In this context, experimental research on As toxicokinetics and toxicodynamics and on modes of toxic action is moving very rapidly. Both aspects are well evidenced by the contributions to the present special issue of Archives of Toxicology. As demonstrated in this issue, there is now accumulating evidence that several mechanisms are involved in the carcinogenicity of arsenic, with a particular impact of oxidative stress and related consequences. As present recommendations of human exposure limits are only pragmatic (ATSDR 2012), this new scientific development can be foreseen to enable very soon the derivation of health-based exposure limits for arsenic at the workplace and in the general environment.

\section{References}

Agusa T, Iwata H, Jujihara J, Kunito T, Takeshita H, Minh TB, Trang PT, Viet PH, Tanhabe S (2009) Genetic polymorphisms in AS3MT and arsenic metabolism in residents of the Red River Delta, Vietnam. Toxicol Appl Pharmacol 236(2):131-141

Agusa T, Kunito T, Kubota R, Inoue S, Fujihara JU, Minh TB, Ha NN, Tu NP, Trang PT, Chamnan C, Takeshita H, Iwata H, Tuyen BC, Viet PH, Tana TS, Tanabe S (2010a) Exposure, metabolism, and health effects of arsenic in residents from arsenic-contaminated groundwater areas of Vietnam and Cambodia: a review. Rev Environ Health 25(3):193-220

Agusa T, Iwata H, Fujihara J, Kunito T, Takeshita H, Minh TB, Trang PT, Viet PH, Tanabe S (2010b) Genetic polymorphisms in glutathione S-transferase (GST) superfamily and arsenic metabolism in residents of the Red River Delta, Vietnam. Toxicol Appl Pharmacol 242(2):352-362

Anwar-Mohamed A, Abdelhamid G, Amara IE, El-Kadi OS (2012) Differential modulation of aryl hydrocarbon receptor regulated enzymes by arsenite in the kidney, lung, and heart of C57BL/6 mice. Arch Toxicol. doi:10.1007/s00204-012-0855-x

ATSDR [Agency for Toxic Substances and Disease Registry] (2012) Arsenic toxicity. What are the standards and regulation for arsenic exposure? Environmental Health and Medicine Education, Course WB 1576. ATSDR, Atlanta GA. Available via: http://www.atsdr.cdc.gov/csem/csem.asp?csem $=1 \& p 0=8$. Accessed 29 Apr 2012

Balakumar P, Kaur J (2009) Arsenic exposure and cardiovascular disorders: an overview. Cardiovasc Toxicol 9(4):169-176

Baoshan Z, Binbin W, Zhenhua D, Daixing Z, Yunshu Z, Chen Z, Chaochang C, Finkelman RB (2005) Endemic arseniosis caused by indoor combustion of high-As coal in Guizhou Province, P.R. China. Environ Geochem Health 27:521-528

Bencko V, Rames J, Fabiánová E, Pesek J, Jakubis M (2009) Ecological and human health risk aspects of burning arsenic-rich coal. Environ Geochem Health 31:239-243

Brima EI, Haris PI, Jenkins RO, Polya DA, Gault AG, Harrington CF (2006) Understanding arsenic metabolism through a comparative study of arsenic levels in the urine, hair and fingernails of healthy volunteers from three unexposed ethnic groups in the United Kingdom. Toxicol Appl Pharmacol 216(1):122-130

Brothwell D, Grime G (2002) The analysis of the hair oft he Neolithic Iceman. In: Lynnerup N, Andreasen C, Berglund J (eds) Mummies in a Mew Millenium. Proceedings of the 4th world congress on mummy studies. Nuuk, Greenland, Sep 4-10, 2001. Greenland National Museum and Archives and Danish Polar Center, pp 66-69 
Chang Y-Y, Hsu C-H, Kuo T-C, Hou D-R, Kao Y-H, Huang R-N (2012) Characterization of the role of protein-cysteine residues in the binding with sodium arsenite. Arch Toxicol. doi: 10.1007/s00204-012-0828-0

Chen SC, Chen CC, Kuo CY, Huang CH, Lin CH, Lu ZY, Chen YY, Lee HS, Wong RH (2012) Elevated risk of hypertension induced by arsenic exposure in Taiwanese rural residents: possible effects of manganese superoxide dismutase (MnSOD) and 8-oxoguanine DNA glycolylase (OGG1) genes. Arch Toxicol. doi:10.1007/ s00204-011-0797-8

Chouhan S, Flora SJ (2010) Arsenic and fluoride: two major ground water pollutants. Indian J Exp Biol 48(7):666-678

Cleland B, Tsuchiya A, Kalman DA, Dills R, Burbacher TM, White JW, Faustman EM, Marien K (2009) Arsenic exposure within the Korean community (United States) based on dietary behavior and arsenic levels in hair, urine, air, and water. Environ Health Perspect 117(4):632-638

Concha G, Nermell B, Vahter M (2006) Spatial and temporal variations in arsenic exposure via drinking-water in Northern Argentina. J Health Popul Nutr 24(3):317-326

de Fátima Pinheiro Pereira S, Saraiva AF, de Alencar MI, Ronan DE, de Alencar WS, Oliveira GR, e Silva CS, Miranda RG (2010) Arsenic in the hair of individuals in Santana-AP-Brazil: significance of residence location. Bull Environ Contam Toxicol 84(4):368-372

Dopp E, von Recklinghausen U, Hartmann LM, Stueckradt I, Pollok I, Rabieh S, Hao L, Nussler A, Katier C, Hirner AV, Rettenmeier AW (2008) Subcellular distribution of inorganic and methylated arsenic compounds in human urothelial cells and human hepatocytes. Drug Metab Dispos 36(5):971-979

Dopp E, Klingerman AD, Diaz-Bone RA (2010) Organoarsenicals. Uptake, metabolism, and toxicity. Met Ions Life Sci 7:231-265

Emadi A, Gore SD (2010) Arsenic trioxide-an old drug rediscovered. Blood Rev 24(4-5):191-199

Escobar-García DM, Del Razo LM, Sanchez-Peña LC, Mandeville PB, Lopez-Campos C, Escudero-Lourdes C (2012) Association of glutathione S-transferase $\Omega$ polymorphisms (A140D and E208K) with the expression of interleukin 8 (IL-8), transforming growth factor beta (TGF- $\beta$ ) and apoptotic protease activating factor 1 (Apaf-1) in humans chronically exposed to arsenic in drinking water. Arch Toxicol. doi:10.1007/s00204-012-0802-x

Flora SJ (2011) Arsenic-induced oxidative stress and its reversibility. Free Radic Biol Med 51(2):257-281

Forslind B, Li HK, Malmqvist KG, Wiegleb D (1985) Elemental analysis of hair fibres using PIXE-a population study of sulphur and zinc content. Sci Total Environ 42:219-222

Gault AG, Rowland HA, Charnock JM, Wogelius RA, GomezMorilla I, Vong S, Leng M, Samreth S, Sampson ML, Polya DA (2008) Arsenic in hair and nails of individuals exposed to arsenic-rich groundwaters in Kandal province, Cambodia. Sci Total Environ 393(1):168-176

Guha Mazumder D, Dasgupta UB (2011) Chronic arsenic toxicity: studies in West Bengal, India. Kaohsiung J Med Sci 27(9): 360-370

Hanh HT, Kim KW, Bang S, Hoa NM (2011) Community exposure to arsenic in the Mekong river delta, Southern Vietnam. J Environ Monit 13(7):2025-2032

Harrison AP, Cattani I, Turfa JM (2010) Metallurgy, environmental pollution and the decline of Etruscan civilisation. Environ Sci Pollut Res 17:165-180

Hayakawa T, Kobayashi Y, Cui X, Hirano S (2005) A new metabolic pathway of arsenite: arsenic-glutathione complexes are substrates for human methyltransferase Cyt19. Arch Toxicol 79(4):183-191

Huang RN, Lee TC (1996) Cellular uptake of trivalent arsenite and pentavalent arsenate in $\mathrm{KB}$ cells cultures in phosphate-free medium. Toxicol Appl Pharmacol 136(2):243-249
Jomova K, Valko M (2011) Advances in metal-induced oxidative stress and human disease. Toxicology 283(2-3):65-87

Jomova K, Jenisova Z, Feszterova M, Baros S, Liska J, Hudecova D, Rhodes CJ, Valko M (2011) Arsenic: toxicity, oxidative stress and human disease. J Appl Toxicol 31(2):95-107

Juárez-Reyes A, Jiménez-Capdeville ME, Delgado JM, Ortiz-Pérez D (2009) Time course of arsenic species in the brain and liver of mice after oral administration of arsenate. Arch Toxicol 83:557-563

Kamath SU, Pemiah B, Sekar RK, Krishnaswamy S, Sethuraman S, Krishnan UM (2012) Mercury-based traditional herbo-metallic preparations: a toxicological perspective. Arch Toxicol. doi: 10.1007/s00204-012-0826-2

Kazi TG, Baig JA, Shah AQ, Kandhro GA, Khan S, Afridi HI, Kolachi NF, Wadhwa SK, Shah F, Baig AM (2011) Determination of arsenic in scalp hair samples from exposed subjects using microwave-assisted digestion with and without enrichment based on cloud point extraction by electrothermal atomic absorption spectrometry. J AOAC Int 94(1):293-299

Kim KW, Chanpiwat P, Hanh HT, Phan K, Sthiannopkao S (2011) Arsenic geochemistry of groundwater in Southeast Asia. Front Med 5(4):420-433

Kintz P, Ginet M, Merques N, Cirimele V (2007) Arsenic speciation of two specimens of Napoleon's hair. Forensic Sci Int 170(2-3):204-206

Kobayashi Y, Negishi T, Mizumura A, Watanabe T, Hirano S (2008) Distribution and excretion of arsenic in Cynomologus monkey following repeated administration of diphenylarsinic acid. Arch Toxicol 82:553-561

Laib RJ, Moritz M (1989) Investigation of tumor initiating and/or cocarcinogenic properties of arsenite and arsenate with the rat liver foci bioassay. Exp Pathol 37(1-4):231-233

Lewin L (1929) Die Gifte in der Weltgeschichte. Julius Springer, Berlin, pp 157-166

Lin GF, Du H, Chen JG, Lu HC, Guo WC, Golka K, Shen JH (2010) Association of XPD/ERCC2 G23591A and A35931C polymorphisms with skin lesion prevalence in a multi-ethnic, arseniasishyperendemic village exposed to indoor combustion of high arsenic coal. Arch Toxicol 84(1):17-24

Lin GF, Gong SY, Wei C, Chen JG, Golka K, Shen JH (2012) Co-occurrence of arseniasis and fluorosis due to indoor combustion of high fluorine and arsenic content coal in a rural township on Northwest China: epidemiological and toxicological aspects. Arch Toxicol. doi:10.1007/s00204-011-0792-0

Liu J, Lu Y, Wu Q, Goyer RA, Waalkes MP (2008) Mineral arsenicals in traditional medicines: orpiment, realgar, and arsenolite. J Pharmacol Exp Ther 326(2):363-368

Liu BJ, Wu FC, Deng QJ, Mo CL, Zhu J, Zeng L, Fu ZY, Li W (2009) Pollution characteristics of antimony, arsenic and mercury in human hair at Xikuangshan antimony mining area and Guyang City, China (in Chinese). Huan Jing Ke Xue 30(3):907-912

Liu CP, Luo CL, Gao Y, Li FB, Lin LW, Wu CA, Li XD (2010) Arsenic contamination and potential health risk implications at an abandoned tungsten mine, Southern China. Environ Pollut 158(3):820-826

Ma Y, Niu R, Sun Z, Wang J, Luo G, Zhang J Wang J (2012) Inflammatory responses induced by fluoride and arsenic at toxic concentration in rabbit aorta. Arch Toxicol. doi:10.1007/s00204012-0803-9

Manna P, Sinha M, Sil PC (2008) Arsenic-induced oxidative myocardial injury: protective role of arjunolic acid. Arch Toxicol 82:137-149

McClintock TR, Chen Y, Bundschuh J, Oliver JT, nNavoni J, Olmos V, Lepori EV, Ahsan H, Parvez F (2011) Arsenic exposures in Latin America: biomarkers, risk assessments and related health effects. Sci Total Environ [Epub ahead of print] 
Naraharisetti SB, Aggarwal M, Sarkar SN, Malik JK (2008) Concurrent subacute exposure to arsenic through drinking water and Malathion via diet in male rats: effects on hepatic drugmetabolizing enzymes. Arch Toxicol 82:543-551

Oeggl K (2009) The significance of the Tyrolean Iceman for the archeobotany of Central Europe. Veget Hist Archeobot 18:1-11

Orloff K, Mistry K, Metcalf S (2009) Biomonitoring for environmental exposures to arsenic. J Toxicol Environ Health B Crit Rev 12(7):509-524

Pandey PK, Yadav S, Pandey M (2007) Human arsenic poisoning issues in Central-East Indian locations: biomarkers and biochemical monitoring. Int $\mathrm{J}$ Environ Res Public Health 4(1): $15-22$

Pimparker BD, Bhave A (2010) Arsenicosis: review of recent advances. J Assoc Physicians India 58:617-624

Roychowdhury T (2010) Groundwater arsenic contamination in one of the 107 arsenic-affected blocks in West Bengal, India: status, distribution, health effects and factors responsible for arsenic poisoning. Int J Environ Health 213(6):414-427

Sanz E, Muñoz-Olivas R, Cámara C, Sengupta MK, Ahamed S (2007) Arsenic speciation in rice, straw, hair and nails samples from the arsenic-affected areas of Middle and Lower Ganga plain. J Environ Sci Health A Tox Hazard Subst Environ Eng 42(12): 1695-1705

Shah AQ, Kazi TG, Baig JA, Afridi HI (2011) Correlation between arsenic concentration in fish and human scalp hair of people living in arsenic-contaminated and non-contaminated areas of Pakistan. Biol Trace Elem Res 144(1-3):197-204

Shi H, Shi X, Liu KJ (2004) Oxidative mechanism of arsenic toxicity and carcinogenesis. Mol Cell Biochem 255:67-78

Singh AP, Goel RK, Kaur T (2011) Mechanisms pertaining to arsenic toxicity. Toxicol Int 18(2):87-93

Tokar EJ, Diwan BA, Thomas DJ, Waalkes MP (2012) Tomors and proliferative lesions in adult offspring after maternal exposure to methylarsenous acid during gestation in CD1 mice. Arch Toxicol. doi:10.1007/s00204-012-0820-8

Tseng CH (2002) An overview on peripheral vascular disease in blackfood disease-hyperendemic villages in Taiwan. Angiology 53(5):529-537

Tseng H-Y, Liu Z-M, Huang H-S (2012) NADPH oxidase-produced superoxide mediates EGFR transactivation by $\mathrm{c}-\mathrm{Src}$ in arsenic trioxide-stimulated human keratinocytes. Arch Toxicol. doi: 10.1007/s00204-012-0856-9
Uchino T, Roychaudhury T, Ando M, Tokunaga H (2006) Intake of arsenic from water, food composites and excretion through urine, hair from a studied population in West Bengal, India. Food Chem Toxicol 44(4):455-461

Wang Z, Guo X, Bai G, Lei Y (2007) Analysis of risk factors of skin lesions from burning high-arsenic-contaminated coal in Southern Shanxi Province (in Chinese). Wei Sheng Yan Jiu 36(3):343-346

Wang L, Kou M-C, Weng C-Y, Hu L-W, Wang Y-J, Wu M-J (2012) Arsenic modulates heme oxygenase-1, interleukine- 6 and vascular endothelial growth factor expression in endothelial cells: roles of ROS, NF- $\kappa \mathrm{B}$ and MAPK pathways. Arch Toxicol. doi: 10.1007/s00204-012-0845-Z

WHO (1996) Guidelines for drinking-water quality. Health criteria and other supporting information. World Health Organization, Geneva, 2nd edn, vol 2

WHO (2001) Arsenic and arsenic compounds. Environmental Health Criteria Monographs 224. World Health Organization, Geneva, 2nd edn. http://www.inchem.org/pages/ehc.html. Accessed 17 Feb 2012

Wu F, Liu B, Mo C, Chen B, Corns W, Liao H (2011) Health risk associated with dietary co-exposure to high levels of antimony and arsenic in the world's largest antimony mine area. Sci Total Environ 409(18):3344-3351

Xu Y, Li Y, Pang Y, Ling M, Shen L, Jiang R, Zhao J, Zhou J, Wang X, Liu Q (2012) Blockade of p53 by HIF- $2 \alpha$, but not HIF- $1 \alpha$, is involved in arsenite-induced malignant transformation of human bronchial epithelial cells. Arch Toxicol. doi:10.1007/s00204012-0810-x

Yajima I, Uemura N, Nizam S, Khalequzzaman Md, Thang ND, Kumasaka MY, Akhand AA, Shekhar HU, Nakajima N, Kato M (2012) Barium inhibits arsenic-mediated apoptotic cell death in human squamous cell carcinoma cells. Arch Toxicol. doi: 10.1007/s00204-012-0848-9

Yanez J, Fierro V, Mansilla H, Figueroa L, Cornejo L, Barnes RM (2005) Arsenic speciation in human hair: a new perspective for epidemiological assessment in chronic arsenicism. J Environ Monit 7(12):1335-1341

Yen Y-P, Tsai K-S, Chan Y-W, Huang C-F, Yang R-S, Liu S-H (2012) Arsenic induces apoptosis through a reactive oxygen species-induced endoplasmatic reticulum stress and mitochondrial dysfunction pathway. Arch Toxicol. doi:10.1007/s00204012-0864-9 